\title{
Evidence that Precipitin Cross-reactions between Listeria, Erysipelothrix and Bacillus licheniformis are not due to the Rantz Antigen
}

\author{
By PHYLlis E. PEASE, LINDA NICHOLLS AND M. R. STUART* \\ Department of Bacteriology, University of Birmingham, \\ Birmingham B15 2 TJ
}

(Received 29 June 1972; revised 8 August 1972)

SUMM A R Y

An investigation involving gel-diffusion, haemagglutination and absorption tests has been made to determine whether cross-reactions in gel-diffusion precipitin tests between Listeria monocytogenes, Erysipelothrix rhusiopathiae and Bacillus licheniformis observed in this laboratory were due to the Rantz antigen. It is concluded that they were not.

\section{INTRODUCTION}

The Rantz antigen is demonstrable by the technique of haemagglutination, and is common to many species of Gram-positive bacteria. Much weight appears to be attached by contemporary systematists to the suggestion of Rantz (quoted by Seeliger, 196r) that this antigen is responsible for the immunological cross-reactions, between Listeria and other Gram-positive species, that occur in gel-diffusion precipitin tests.

The purpose of this study was to determine whether the cross-reactions, observed in such tests, in this laboratory, between Listeria monocytogenes, Erysipelothrix rhusiopathiae and Bacillus licheniformis were, in fact, due to the Rantz antigen.

\section{METHODS}

Bacterial strains. These were obtained from the following sources. National Collection of Type Cultures - Listeria monocytogenes NCTC 52 I4, 5105, 5348, 7973, 10357, Erysipelothrix rhusiopathiae NCTC I0383, Bacillus licheniformis NCTC I034I, Bacillus lentus NCTC4824, Bacillus firmus NCTC10335, Bacillus subtilis NCTC 3610 , Bacillus carotovorus NCTC4821; Dr W. C. Eveland, Michigan - Listeria monocytogenes $320 \mathrm{I}$; isolations made in this laboratory - Bacillus licheniformis I, 2 and 3.

Preparation of antigens. For gel-diffusion tests heavy heat-killed, washed suspensions of bacteria in $0.2 \%(\mathrm{v} / \mathrm{v})$ formol saline and ultrasonically disintegrated were used. The Rantz antigens were prepared by growing the organisms on B.B.L. Trypticase Soya Agar plates for $\mathrm{I} 8 \mathrm{~h}$, scraping off the growth into $\mathrm{pH} 7.3$ phosphate-buffered saline, centrifuging at I $1000 \mathrm{~g}$, discarding the bacterial deposit and heating the supernatant (the antigen) at $56{ }^{\circ} \mathrm{C}$ for I h to destroy haemolytic activity.

Sensitization of erythrocytes. Rabbit erythrocytes were collected in heparin (Evans Medical Io $\mathrm{ml}$ tube), washed thrice in phosphate-buffered saline of $\mathrm{pH} 7 \cdot 3$ and stored in Alsever's solution until used, when they were re-washed in buffer. For sensitization $0.2 \mathrm{ml}$ of packed

* Present address: Botany Department, University of Rhodesia, Private Bag I67 H. Salisbury, Rhodesia. 


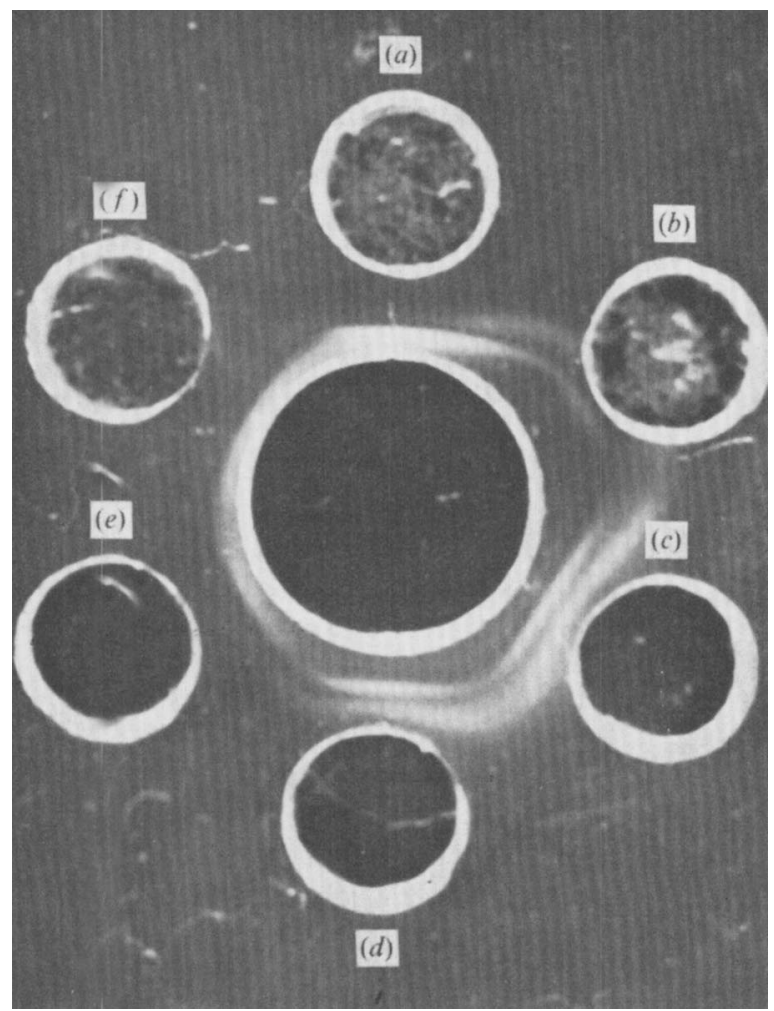

Fig. I. (a) Erysipelothrix rhusiopathiae NCTC 10383 antigen. (b) Listeria monocytogenes NCTC 10357 antigen. (c) Bacillus licheniformis I antigen. (d) Listeria monocytogenes NCTC 7973 antigen. (e) Bacillus licheniformis 2 antigen. $(f)$ Bacillus licheniformis 3 antigen. Central well: Listeria monocytogenes NCTC 5214 antiserum.

erythrocytes was added to $2.0 \mathrm{ml}$ of antigen and incubated at $37{ }^{\circ} \mathrm{C}$ in a water bath for $\mathrm{I} \mathrm{h}$ with occasional shaking. After centrifugation the erythrocytes were washed with buffer solution and finally resuspended in the buffer solution to give a $2 \%(\mathrm{v} / \mathrm{v})$ suspension.

The haemagglutination test. Rabbit antisera were diluted serially twofold in haemagglutination trays and an equal volume of sensitized erythrocyte suspension was added to each dilution. As controls unsensitized erythrocyte suspensions were added to similar dilutions of serum and sensitized cells in phosphate buffer alone. These controls were included in each test. The trays were incubated at $37^{\circ} \mathrm{C}$ for $\mathrm{I} h$ and then read.

Absorption test. This was carried out by scraping the growth from an $\mathrm{I} 8 \mathrm{~h}$ agar plate culture of bacteria into $5 \mathrm{ml}$ phosphate-buffered saline of $\mathrm{pH} \mathrm{7 \cdot 3}$. This bacterial suspension was centrifuged and I $\mathrm{ml}$ of antiserum was added to the deposit. This was shaken at $37^{\circ} \mathrm{C}$ for $\mathrm{I} h$ and centrifuged. Gel-diffusion and Rantz tests were carried out on the supernatant.

Antisera were prepared in rabbits by giving two subcutaneous injections of $\mathrm{I} \mathrm{ml}$ of antigen plus I $\mathrm{ml}$ of Freund's adjuvant (Bacto) at an interval of I4 days. After a further 2 weeks a series of subcutaneous injections of $\mathrm{I} \mathrm{ml}$ of the antigen alone was given on ten occasions over 3 weeks. This procedure was usually sufficient to produce antisera capable of giving rise to strong lines of precipitation in gel diffusion tests set up against homologous antigens. 
Table I. Agglutination titres shown in the tests for the Rantz antigen

Antigens

\begin{tabular}{|c|c|c|c|c|c|c|}
\hline $\begin{array}{l}\text { Antisera } \\
\text { Listeria } \\
\text { nonocytogenes }\end{array}$ & $\begin{array}{c}\text { Bacillus } \\
\text { licheniformis } \\
\mathrm{I}^{*}\end{array}$ & $\begin{array}{c}\text { Bacillus } \\
\text { licheniformis } \\
\text { NCTC } 10341\end{array}$ & $\begin{array}{l}\text { Bacillus } \\
\text { lentus }\end{array}$ & $\begin{array}{l}\text { Bacillus } \\
\text { firmus }\end{array}$ & $\begin{array}{l}\text { Bacillus } \\
\text { subtilis }\end{array}$ & $\begin{array}{c}\text { Bacillus } \\
\text { carotovorus }\end{array}$ \\
\hline NCTC $52 \mathrm{I}$ & $1 / 80$ & $<1 / 20$ & $1 / 160$ & $1 / 10240$ & $1 / 10240$ & $\mathrm{I} / 640$ \\
\hline NCTC 5105 & $1 / 320$ & $1 / 1280$ & $1 / 640$ & $\mathrm{I} / 1280$ & $I / 2560$ & $1 / 640$ \\
\hline
\end{tabular}

* Strains I, 2 and 3 appeared to be identical in all respects, and I was therefore used for this test, together with the type strain.

\section{RESULTS AND DISCUSSION}

Gel diffusion. Results are shown in Fig. I, where continuity of precipitin lines indicates the presence of antigenic components common to strains of Erysipelothrix rhusiopathiae, Listeria monocytogenes and Bacillus licheniformis. Rantz antigen preparations failed to produce precipitin lines in comparable tests.

Rantz tests. Results are shown in Table I. The tests were easy to read and although no titres as high as those obtained by other workers (Anzai, Neter \& Gorzynski, 1960; Neter, Anzai \& Gorzynski, 1960) were obtained, significant titres occurred with two of the Listeria monocytogenes sera, namely NCTC strains 5214 and 5105. Lower titres were observed with antisera raised in the L. monocytogenes $320 \mathrm{I}$ and 5348, and Bacillus licheniformis I. Negative results were obtained with Erysipelothrix rhusiopathiae antiserum.

The negative reaction with Erysipelothrix rhusiopathiae antiserum in the Rantz test and the failure of the Rantz antigenic preparations to react in gel-diffusion tests suggests that the Rantz antigen and the gel-precipitin antigen are different.

This was confirmed in an absorption test. Listeria monocytogenes 5214 antiserum was absorbed with a suspension of Bacillus lentus. In a test for Rantz antibody using antigen prepared from $B$. carotovorus in parallel with unabsorbed antiserum the titre had fallen from $\mathrm{I} / 640$ to $\mathrm{I} / 4$, whereas in a gel-diffusion test against $B$. licheniformis $\mathrm{I}$ the absorbed serum still caused the production of a line of precipitation.

It seems likely that other cross-reactions between Listeria monocytogenes and other Gram-positive bacteria (Seeliger, 196I), demonstrable in precipitin reactions, are not caused by the Rantz type of antigen.

\section{REFERENCES}

Anzal, H., Neter, E. \& Gorzynski, E. A. (1960). Demonstration of Rantz antigen in members of the genus Bacillus. Journal of Bacteriology 8o, I 42-143.

Neter, E., ANZAI, H. \& Gorzynski, E. A. (1960). Identification of an antigen common to Listeria monocytogenes and other bacteria. Proceedings of the Society for Experimental Biology and Medicine 105, I 3 I-I34.

Seeliger, H. P. R. (196I). Listeriosis, 2nd edn. Basel and New York: S. Karger. 